\title{
Sëjomainų ir priešsèlių poveikis su auginamų javų derliumi išnešamų maisto medžiagų kiekiui
}

\section{Darija Jodaugiené,}

Vaclovas Bogužas,

\section{Romutè Mikučionienè,}

Ingè Auželienè,

\section{Romualdas Zemeckis}

Aleksandro Stulginskio universitetas, Studentu g. 11,

LT-53361 Akademija, Kauno $r$.

El.paštas:darija.jodaugiene@asu.lt
Lauko eksperimentas atliktas 1967-2012 m. Aleksandro Stulginskio universiteto Bandymų stotyje, vidutinio sunkumo karbonatingame giliau glejiškame išplautžemyje.

Javai auginti aštuoniose sèjomainose: trilaukèje, javų, Norfolko, pašarinëje, sideracinëje, intensyviojoje, lauko be kaupiamųjų ir lauko su kaupiamaisiais augalais bei rugių monopasèlyje. Žieminiai rugiai auginti penkiose sëjomainose po šių priešselių: juodojo pūdymo, lubinų ir rapsų žaliajai trą̌̌ai, daugiamečių žolių I ir II naudojimo metų (toliau - I ir II n. m.) ir monopasèlyje; žieminiai kviečiai - keturiose sejjomainose: po juodojo pūdymo, vikių ir avižų mišinio ir po daugiamečių žolių I n. m.; vasariniai miežiai - septyniose sẻjomainose: po avižų, žieminių rugių, bulvių, kukurūzų, pašarinių bei cukrinių runkelių; avižos - trijose sèjomainose: po vasarinių miežių, žieminių rugių ir kviečių.

Nustatyta, kad išnešamų maisto medžiagų kiekiai priklausẻ nuo javų derlingumo ir skyrėsi auginant juos po įvairių priešsèlių. Atlikta koreliacinè ir regresinė analizè parodè, kad augalų pagrindinès ir šalutinès produkcijos derliuje sukauptas maisto medžiagų kiekis buvo skirtingas žieminių ir vasarinių javų pasèliuose. Didèjant žieminių rugių ir žieminių kviečiu grūdų derlingumui $\left(\mathrm{t} \mathrm{ha}^{-1}\right)$ patikimai didesni azoto $\left(r=0,429^{*}, r=0,836^{*}\right)$, fosforo $\left(r=0,516^{\star}, r=0,918^{\star}\right)$ ir kalio $\left(r=0,681^{* *}, r=0,735^{*}\right)$ kiekiai $\left(\mathrm{kg} \mathrm{t}^{-1}\right)$ buvo sukaupti šiu javų grūduose. Didëjant šiaudų derlingumui juose patikimai didëjo azoto $\left(r=0,413^{*}, r=0,930^{* *}\right)$ ir fosforo $\left(r=0,425^{*}, r=0,773^{*}\right)$ kaupimas, tačiau mažèjo kalio $\left(r=-0,327^{*}\right.$, $\left.r=-0,379^{\star}\right)$. Azoto $\left(r=-0,716^{*}, r=-0,998^{* *}\right)$, fosforo $\left(r=-0,322^{*}, r=-0,873^{*}\right)$ ir kalio $\left(r=-0,302^{*}, r=-0,517^{*}\right)$ kiekiai vasarinių miežių ir avižų grūduose buvo atvirkščiai proporcingi jų derlingumui. Didèjant vasarinių miežių ir avižų šiaudų derlingumui azoto kiekis mažėjo $\left(r=-0,594^{\star}, r=-0,991^{\star *}\right)$. Fosforo $\left(r=-0,341^{\star}\right)$ ir kalio $\left(r=-0,390^{\star}\right)$ kiekiai mažějo didèjant avižų šiaudų derlingumui. Patikimų priklausomumų tarp vasarinių miežių šiaudų derlingumo ir fosforo bei kalio kiekių juose nebuvo nustatyta.

Raktažodžiai: sẻjomainos, priešsèliai, javai, derlingumas, su derliumi išnešamų maisto medžiagų kiekis

\section{IVADAS}

Pagrindinis maisto medžiagų šaltinis augalams yra dirvožemis, trąšos ir atmosfera. Nūdienos ūkininkavimo sąlygas lemia ne tik naujos žemès dirbimo ir augalų auginimo technologijos, bet ir dirvožemio derlingumas bei jo degradacija. Dirvožemio derlingumą nulemia organinių medžiagų kiekis dirvožemyje, nes būtent humusas yra žemès ūkio augalų maisto medžiagų (N, P, K ir mikroelementų) šaltinis. Pastaraisiais metais Lietuvoje ypač sumažèjo augalininkystės-gyvulininkystès ūkių, tačiau padaugèjo prekinių augalininkystès ūkių. Vykdant aktyvią žemès ūkio veiklą, dirvožemyje sparčiai mažeja organinès medžiagos (humuso), nes jos šaltiniu tampa tik augalinès liekanos. Šiu liekanų masè ir cheminè sudètis veikia ne tik humuso atsargas, bet ir jo kokybinę sudètị (Bakšienè 
ir kt., 2013; Tripolskaja ir kt., 2014). Dirvožemio naudojimas lemia humuso C:N santyki (Šlepetiené ir kt., 2007; Feizienė ir kt., 2008; Aleinikovienè, 2009; Breuning-Madsen et al., 2009; Lagomarsino et al., 2009). Tyrimai rodo, kad sejomainoje vyraujant javams per metus dirvožemyje netenkama apie 40-100 $\mathrm{kg} \mathrm{ha}^{-1}$ organinès anglies. Jei šiaudai išvežami iš lauko ir tręšiama tik mineralinèmis trąšomis, šie nuostoliai siekia net $200 \mathrm{~kg} \mathrm{ha}^{-1}$. Labai svarbu išsaugoti dirvožemio derlingumą, todèl augalų mitybai paimtas maisto medžiagas būtina grąžinti i dirvožemị organinių ir mineralinių trąšų pavidalu.

Skirtingos augalų rūšys derliui formuoti nevienodai efektyviai naudoja trąšas, todèl nuo jų paskirstymo sèjomainoje didele dalimi priklauso sejjomainos produktyvumas (Janušauskaitė, Mašauskas, 2006). Lietuvoje šiuo klausimu yra sukaupta daug tyrimų medžiagos (Greimas, Janušienè, 1994; Tripolskaja, 1994; Plesevičienè, Gužys, 1997; Zakarauskaite, Grigaliūnienė, 2001; Krikštaponyte, 2002; Greimas, 2003, Mažvila ir kt., 2006). Griežtejjant gamtos saugos reikalavimams, ypač aktualu išnaudoti visus potencialius veiksnius, kad būtų išaugintas optimalus augalu derlius, tinkamai sureguliuotas dirvožemio našumas, maisto medžiagu apykaita ir balansas. Norint kuo tiksliau nustatyti optimalias tręšimo normas, reikia gerai apskaičiuoti maisto medžiagų išteklius dirvožemyje, jų sunaudojimą derliui gauti, taip pat ištirti, kiek jų $\mathfrak{i}$ dirvą patenka su krituliais ir kiek nuostolių susidaro per ištisą metų ciklą. Todèl žemdirbiams rekomenduojama skaičiuoti maisto medžiagų balansą. ES aplinkosaugos politikoje („Nitratų“ direktyva 91/676/EEC, Tarybos reglamentas 1782/2003/EC) ì maisto medžiagų balansą žiūrima kaip ì priemonę, galinčią sumažinti vandenų taršą, reikalaujama skaičiuoti tik azoto balansą, o fosforo balansą skaičiuoti rekomenduojama. Sudarant tręšimo planus nustatyti azoto, fosforo ir kalio balansai gali būti kaip priemonè racionaliau ir taupiau naudoti organines bei mineralines trąšas.

Tyrimų tikslas - nustatyti sejjomainų ir priešsèlių poveikị azoto, fosforo ir kalio išnešimui su javų grūdų ir šiaudų derliumi.

\section{METODAI IR SĄLYGOS}

Su javų grūdų ir šiaudų derliumi iš dirvožemio išneštų maisto medžiagų kiekio dinamikai ịvertinti panaudoti unikalūs ASU Bandymų stotyje nuo
1967 m. vykdomų augalų kaitos tyrimų (sėjomainų kolekcijos) duomenys. Šis stacionarus lauko eksperimentas įrengtas prof. Antano Stancevičiaus iniciatyva ir tęsiamas iki šiol. Lyginamos devynios skirtingos sejomainos ir skirtingai prižiūrimi rugių bei kukurūzų monopasèliai.

Pati paprasčiausia sejjomaina - trilaukè: 1) juodasis pūdymas, 2) žieminiai rugiai, 3) avižos.

Javų sejomainoje 75 \% sudaro javai: 1) vikiųavižu mišinys žaliajam pašarui, 2) žieminiai kviečiai, 3) avižos, 4) vasariniai miežiai.

Norfolko sëjomaina: 1) daugiametès žolès I n. m., 2) žieminiai kviečiai, 3) bulvès, 4) vasariniai miežiai su issèliu.

Pašarinę séjomainą sudaro $50 \%$ daugiamečių žolių ir kiti augalai, skirti pašarui (išskyrus linus, auginamus kaip prekinius augalus): 1) daugiametès žolès I n. m., 2) daugiametès žolès II n. m., 3) daugiametès žolès III n. m., 4) daugiametès žolès IV n. m., 5) linai, 6) kukurūzai, 7) pašariniai runkeliai, 8) miežiai su ịsèliu.

Sideracinèje sẻjomainoje 33,3 \% augalų (rapsai ir lubinai) auginami žaliajai trąšai: 1) lubinai žaliajai trąšai, 2) žieminiai rugiai, 3) žieminiai rapsai žaliajai trąšai, 4) žieminiai rugiai, 5) bulvès, 6) vasariniai miežiai.

Intensyviojoje sejjomainoje šešiuose laukuose per metus gaunami devynių augalų derliai: 1) daugiametès žolès I n. m., 2) žieminiai rugiai $\rightarrow$ žieminiai rapsai žaliajai trąšai, 3) ankstyvosios bulvės, 4) žieminiai rugiai žaliajam pašarui $\rightarrow$ kukurūzai, 5) vasariniai miežiai $\rightarrow$ baltoji garstyčia, 6) vikiųavižų mišinys žaliajam pašarui su ịsèliu.

Lauko sejomainą be kaupiamujuc augalų sudaro šeši rotacijos nariai: 1) juodasis pūdymas, 2) žieminiai kviečiai su įsèliu, 3) daugiametès žolès I n. m., 4) daugiametès žolès II n. m., 5) žieminiai rugiai, 6) vasariniai miežiai.

Lauko sejomainą su kaupiamaisiais augalais sudaro aštuoni rotacijos nariai: 1) juodasis pūdymas, 2) žieminiai kviečiai su įsèliu, 3) daugiametès žolès I n. m., 4) daugiametès žolès II n. m., 5) žieminiai rugiai, 6) cukriniai runkeliai, 7) vasariniai miežiai, 8) avižos.

Žieminių rugių monopasèlis auginamas taip pat nuo $1967 \mathrm{~m}$. pagal keturias skirtingas technologijas: 1) žieminiai rugiai netręšti ir nepurkšti, 2) žieminiai rugiai netręšti, bet purkšti herbicidais, 3) žieminiai rugiai nepurkšti herbicidais, bet tręšti, 4) žieminiai rugiai tręšti ir purkšti herbicidais. 
Kasmet auginami visi augalai visose sejomainose. Javai auginami aštuoniose sèjomainose: trilaukejje, javų, Norfolko, pašarinejje, sideracinèje, intensyviojoje, lauko be kaupiamųju ir lauko su kaupiamaisiais augalais bei rugių monopasèlyje. Straipsnyje pateikiami žieminių rugių, augintų sėjomainose, duomenys ir jie lyginami su monopasèlyje augintais žieminiais rugiais, tręštais tomis pačiomis trąšomis ir purkštais herbicidais, kaip ir žieminiai rugiai sèjomainose.

Tyrimai vykdyti 46 metus, laikytasi tam laikotarpiui ịprastos kultūrinių augalų auginimo technologijos. Tos pačios rūšies augalams visose sejomainose taikytas vienodas žemès dirbimas, tręšimas, augalų apsaugos priemonès. Miežiai ir avižos tręštos $\mathrm{N}_{80} \mathrm{P}_{65} \mathrm{~K}_{150}$, miežiai su ịsèliu $-\mathrm{N}_{50} \mathrm{P}_{65} \mathrm{~K}_{150}$, žieminiai rugiai $-\mathrm{N}_{90} \mathrm{P}_{65} \mathrm{~K}_{75}$, žieminiai kviečiai $-\mathrm{N}_{70} \mathrm{P}_{60} \mathrm{~K}_{75}$, žieminiai kviečiai su įsèliu $-\mathrm{N}_{50} \mathrm{P}_{60} \mathrm{~K}_{75}$.

Maisto medžiagų kiekiai javų grūduose ir šiauduose nustatyti remiantis direktyvomis: azoto - 72/199/EEB, fosforo - 71/393/EEB, kalio 71/250/EEB.

Apskaičiuoti 46 metų javų derlingumo vidurkiai ir jų paklaidos naudojant kompiuterinę programą SYSTAT10. Tyrimų duomenų tarpusavio priklausomumams įvertinti atlikta koreliacinè ir regresinè analizė taikant kompiuterinę programą STAT iš programų paketo SELEKCIJA (Tarakanovas, Raudonius, 2003), kur priklausomumas vertintas pagal Fišerio kriterijų, kai: ${ }^{\star}$ - statistiškai patikimas pri- klausomumas esant $95 \%,(P \leq 0,01)$, o ** $-99 \%$ $(P \leq 0,01)$ tikimybès lygiui.

\section{TYRIMŲ REZULTATAI IR JŲ APTARIMAS}

Žieminiai rugiai. Ilgalaikiai tyrimai įrodo sèjomainos svarbą žemès ūkio augalų derlingumui. Žieminių rugių grūdų ir šiaudų derlingumas, auginant juos monopasèlyje ir skirtingose sejomainose, ženkliai skyrèsi. Mažiausias derlingumas buvo žieminių rugių, augintų 46 metus monopasèlyje. Vidutiniais 1967-2012 m. duomenimis, žieminių rugių grūdų derlingumas minètame monopasèlyje sieke tik $2,74 \mathrm{t} \mathrm{ha}^{-1}$, o rugius auginant sejjomainose svyravo nuo 3,47 iki 3,97 $\mathrm{t} \mathrm{ha}^{-1}$ (1 pav.).

Geriausiai rugiai derejo auginant juos trilaukejje sejomainoje po juodojo pūdymo, intensyviojoje - po daugiamečių žolių I n. m. ir lauko sejjomainoje su kaupiamaisiais - po daugiamečiu žolių II n. m. Kiek mažesnis žieminių rugių grūdų ir šiaudų derlingumas buvo lauko séjomainoje be kaupiamujų, auginant juos po daugiamečiu žolių II n. m. ir sideracinèje sèjomainoje - po lubinų ir po rapsų.

Sukaupti maisto medžiagų kiekiai, didejjant žieminių rugių grūdų derlingumui, didejjo. Nustatyti teigiami tiesiniai priklausomumai tarp rugiu grūdų derlingumo $\left(\mathrm{t} \mathrm{ha}^{-1}\right)$ ir grūduose sukauptų azoto $\left(r=0,429^{\star}\right)$, fosforo $\left(r=0,516^{*}\right)$ bei kalio

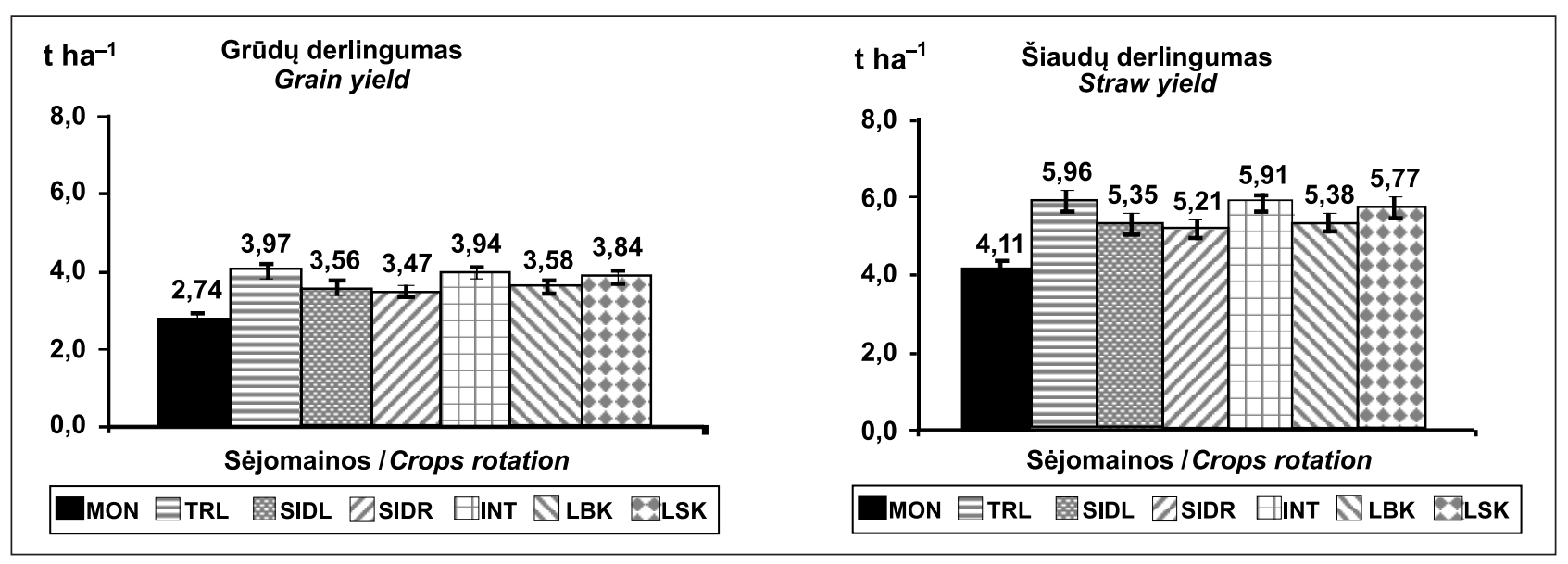

1 pav. Sëjomainų poveikis žieminių rugių derlingumui, 1967-2012 m. Sejjomainos: MON - monopasèlis, TRI - trilaukè, SIDL - sideracinè po lubinų, SIDR - sideracinè po rapsų, INT - intensyvi, LBK - lauko sejomaina be kaupiamųjų, LSK - lauko sejjomaina su kaupiamaisiais augalais

Fig. 1. Effect of crop rotation on winter rye yield, 1967-2012. Crop rotation: MON - monoculture, TRI - three-course, SIDL - green manure rotation after lupine, SIDR - green manure rotation after rape, INT - intensive, LBK - field rotation without row crops, LSK - field rotation with row crops 
$\left(r=0,681^{\star *}\right)$ kiekių $\left(\mathrm{kg} \mathrm{t}^{-1}\right)$. Monopasèlyje azoto kiekis, išnešamas su žieminių rugių grūdų derliumi, nustatytas mažiausias $\left(37,8 \mathrm{~kg} \mathrm{ha}^{-1}\right)$, o auginant rugius po ìvairių priešsèlių - 14,0-66,9 \% didesnis (1 lentelè). Fosforo ir kalio taip pat mažiausia sukaupta žieminių rugių grūduose, augintuose monopasèlyje. Daugiausia fosforo susikaupè rugių grūduose, auginant juos intensyviojoje sejjomainoje po daugiamečių žolių I n. m., o kalio - trilaukèje sejjomainoje po juodojo pūdymo.
Azoto ir fosforo kiekiai žieminių rugių šiauduose, didejjant jų derlingumui, didejo, tačiau kalio kiekis mažéjo. Kalis skatina varpinių javų ląstelių medejimą, todèl manoma, kad dèl to augalo šalutinëje produkcijoje jo mažèjo.

Nustatyti teigiami tiesiniai priklausomumai tarp žieminių rugių šiaudų derlingumo $\left(\mathrm{t} \mathrm{ha}^{-1}\right)$ ir azoto $\left(r=0,413^{\star}\right)$ bei fosforo $\left(r=0,425^{*}\right)$ kiekių $\left(\mathrm{kg} \mathrm{t}^{-1}\right)$ šiauduose, tačiau neigiamas tiesinis priklausomumas tarp rugių šiaudų derlingumo

1 lentelè. Sẻjomainų ir priešsèlių poveikis su žieminių rugių derliumi išnešamų maisto medžiagų kiekiui, 1967-2012 m.

Table 1. Effect of crop rotation and preceding crop on nutrient content taken out with winter rye yield, 1967-2012

\begin{tabular}{|c|c|c|c|c|}
\hline \multirow[b]{2}{*}{$\begin{array}{l}\text { Sëjomaina } \\
\text { Crop rotation }\end{array}$} & \multirow[b]{2}{*}{$\begin{array}{c}\text { Priešsèlis } \\
\text { Preceding crop }\end{array}$} & \multicolumn{3}{|c|}{$\begin{array}{l}\text { Maisto medžiagų kiekiai } \mathrm{kg} \mathrm{ha}^{-1} \\
\text { Nutrient content, } \mathrm{kg} \mathrm{ha}^{-1}\end{array}$} \\
\hline & & 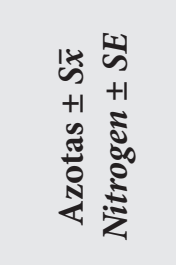 & 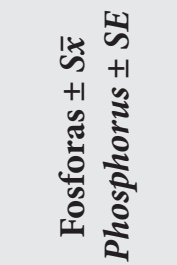 & 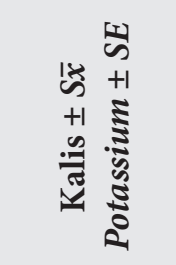 \\
\hline \multicolumn{5}{|c|}{ Su grūdais / with grain } \\
\hline Monopasèlis / Monoculture & Žieminiai rugiai / Winter rye & $37,8 \pm 2,47$ & $5,8 \pm 0,38$ & $8,0 \pm 0,52$ \\
\hline Trilaukè / Three-course & Juodasis pūdymas / Black fallow & $63,1 \pm 2,86$ & $13,9 \pm 0,63$ & $15,9 \pm 0,72$ \\
\hline Sideracinè / Green manure & $\begin{array}{l}\text { Lubinai žaliajai trąšai } \\
\text { Lupine for green manure }\end{array}$ & $43,1 \pm 2,17$ & $15,9 \pm 0,81$ & $12,9 \pm 0,65$ \\
\hline Sideracinè / Green manure & $\begin{array}{l}\text { Rapsai žaliajai trąšai } \\
\text { Rape for green manure }\end{array}$ & $48,0 \pm 2,34$ & $15,6 \pm 0,76$ & $13,2 \pm 0,64$ \\
\hline Intensyvioji / Intensive & $\begin{array}{l}\text { Daugiametès žolès I } \mathrm{n} . \mathrm{m} \text {. } \\
\text { Perennial grasses of the first year of use }\end{array}$ & $59,1 \pm 2,24$ & $17,3 \pm 0,66$ & $14,2 \pm 0,54$ \\
\hline $\begin{array}{l}\text { Lauko be kaupiamujuc / Field } \\
\text { rotation without row crops }\end{array}$ & $\begin{array}{l}\text { Daugiametès žolès II n. m. } \\
\text { Perennial grasses of the second year of use }\end{array}$ & $57,4 \pm 2,60$ & $11,5 \pm 0,52$ & $15,4 \pm 0,70$ \\
\hline $\begin{array}{l}\text { Lauko su kaupiamaisiais } \\
\text { Field rotation with row crops }\end{array}$ & $\begin{array}{l}\text { Daugiametès žolès II n. m. } \\
\text { Perennial grasses of the second year of use }\end{array}$ & $56,9 \pm 2,46$ & $11,2 \pm 0,48$ & $14,2 \pm 0,61$ \\
\hline \multicolumn{2}{|c|}{ Vidutiniškai / Average } & $52,2 \pm 1,84$ & $13.0 \pm 0,44$ & $13,4 \pm 0,47$ \\
\hline \multicolumn{5}{|c|}{ Su šiaudais / with straw } \\
\hline Monopasèlis / Monoculture & Žieminiai rugiai / Winter rye & $23,0 \pm 1,50$ & $3,7 \pm 0,24$ & $17,7 \pm 1,16$ \\
\hline Trilauke / Three-course & Juodasis pūdymas / Black fallow & $38,1 \pm 1,73$ & $6,0 \pm 0,27$ & $25,6 \pm 1,16$ \\
\hline Sideracinè / Green manure & $\begin{array}{l}\text { Lubinai žaliajai trą̌ai } \\
\text { Lupine for green manure }\end{array}$ & $35,4 \pm 1,78$ & $6,4 \pm 0,32$ & $23,1 \pm 1,16$ \\
\hline Sideracinè / Green manure & $\begin{array}{l}\text { Rapsai žaliajai trąšai } \\
\text { Rape for green manure }\end{array}$ & $29,2 \pm 1,42$ & $6,8 \pm 0,33$ & $27,6 \pm 1,35$ \\
\hline Intensyvioji / Intensive & $\begin{array}{l}\text { Daugiametès žolès I } \mathrm{n} . \mathrm{m} \text {. } \\
\text { Perennial grasses of the first year of use }\end{array}$ & $36,6 \pm 1,39$ & $10,6 \pm 0,40$ & $18,3 \pm 0,70$ \\
\hline $\begin{array}{l}\text { Lauko be kaupiamujuc / Field } \\
\text { rotation without row crops }\end{array}$ & $\begin{array}{l}\text { Daugiametès žolès II n. m. } \\
\text { Perennial grasses of the second year of use }\end{array}$ & $41,9 \pm 1,90$ & $5,9 \pm 0,27$ & $26,9 \pm 1,22$ \\
\hline $\begin{array}{l}\text { Lauko su kaupiamaisiais } \\
\text { Field rotation with row crops }\end{array}$ & $\begin{array}{l}\text { Daugiametès žolès II n. m. } \\
\text { Perennial grasses of the second year of use }\end{array}$ & $39,2 \pm 1,69$ & $5,5 \pm 0,24$ & $27,7 \pm 1,19$ \\
\hline \multicolumn{2}{|c|}{ Vidutiniškai / Average } & $34,7 \pm 1,20$ & $6,4 \pm 0,22$ & $23,8 \pm 0,84$ \\
\hline
\end{tabular}


$\left(\mathrm{t} \mathrm{ha}^{-1}\right)$ ir kalio $\left(r=-0,327^{\star}\right)$ kiekio. Mažiausi maisto medžiagu kiekiai susikaupé monopasèlyje augintų žieminių rugių šiauduose. Su sèjomainose augintų rugių šiaudais maisto medžiagų kiekiai išnešami didesni: azoto - 1,27-1,82 karto, fosforo - 1,49-2,87 karto, o kalio - nuo 3,4 \% iki 1,57 karto. Didžiausi azoto kiekiai išnešami su žieminių rugių šiaudais, augintais lauko sejjomainoje be kaupiamųjų po daugiamečių žolių II n. m., fosforo - intensyviojoje sejjomainoje po daugiamečiu žolių I n. m., kalio - lauko sèjomainoje su kaupiamaisiais po daugiamečių žolių II n. m.

Žieminiai kviečiai. Grūdų ir šiaudų derlingumas auginant žieminius kviečius įvairiose sèjomainose skyrèsi. Vidutiniais 1967-2012 m. duomenimis, mažiausias derlingumas gautas juos auginant javų sẻjomainoje po vikių ir avižų mišinio žaliajam pašarui (2 pav.). Viena iš priežasčių, kad šioje sèjomainoje javai sudaro $75 \%$ ir nepakanka vieno dirvą gerinančio sėjomainos nario (vikių ir avižų mišinio), kad užtikrintų didesni žieminių kviečių derlingumą. Didžiausias kviečių derlingumas $\left(4,07 \mathrm{t} \mathrm{ha}^{-1}\right.$ grūdų ir 5,7 t ha ${ }^{-1}$ šiaudų) gautas Norfolko sejjomainoje auginant juos po daugiamečių žolių I n. m. Kiek mažesnis juodojo pūdymo poveikis lauko sejomainose su ir be kaupiamųjų augalų.

Maisto medžiagų kiekiai pagrindinejje produkcijoje, didejjant žieminių kviečių grūdų derlingumui, taip pat didejo. Nustatyti teigiami tiesiniai priklausomumai tarp žieminių kviečių grūdų derlingumo $\left(\mathrm{t} \mathrm{ha}^{-1}\right)$ ir azoto $\left(r=0,836^{\star *}\right)$, fosforo $\left(r=0,918^{\star \star}\right)$ bei kalio $\left(r=0,735^{\star}\right)$ kiekių $\left(\mathrm{kg} \mathrm{t}^{-1}\right)$ grūduose. Dèl šios priežasties su derliumi išnešamų medžiagų kiekis $\left(\mathrm{kg} \mathrm{ha}^{-1}\right)$ buvo tiesiogiai proporcingas žieminių kviečių grūdų derlingumui.

Didžiausi azoto, fosforo ir kalio kiekiai buvo išnešami su žieminių kviečių grūdais, augintais Norfolko sejjomainoje po daugiamečių žolių I n. m.

Azoto ir fosforo kiekiai žieminių kviečių šiauduose, didejjant jų derlingumui, taip pat didejo, tačiau kalio kiekis mažèjo. Nustatyti teigiami tiesiniai priklausomumai tarp žieminių kviečiu šiaudų derlingumo $\left(\mathrm{t} \mathrm{ha}^{-1}\right)$ ir azoto $\left(r=0,930^{\star *}\right)$ bei fosforo $\left(r=0,773^{*}\right)$ kiekių $\left(\mathrm{kg} \mathrm{t}^{-1}\right)$ šiauduose, tačiau neigiamas tiesinis priklausomumas tarp žieminių kviečių šiaudų derlingumo ( $\mathrm{t} \mathrm{ha}^{-1}$ ) ir kalio $\left(r=-0,379^{*}\right)$ kiekio. Didžiausi azoto ir fosforo kiekiai buvo išnešami su žieminių kviečių šiaudais, augintais Norfolko sèjomainoje po daugiamečių žolių I n. m., o kalio - lauko sẻjomainoje be kaupiamųjų augalų po juodojo pūdymo.

Vasariniai miežiai. Grūdų ir šiaudų derlingumas auginant vasarinius miežius ịvairiose sẻjomainose skyrèsi nežymiai. Vidutiniais 1967-2012 m. duomenimis, didžiausias $\left(4,42 \mathrm{t} \mathrm{ha}^{-1}\right)$ miežių derlingumas gautas juos auginant javų sejomainoje po avižų (3 pav.).

Sukaupti maisto medžiagų kiekiai, didejant vasarinių miežių grūdų derlingumui, priešingai nei rugių bei žieminių kviečių, mažèjo. Nustatyti neigiami tiesiniai priklausomumai tarp vasarinių miežių grūdų derlingumo $\left(\mathrm{t} \mathrm{ha}^{-1}\right)$ ir azoto

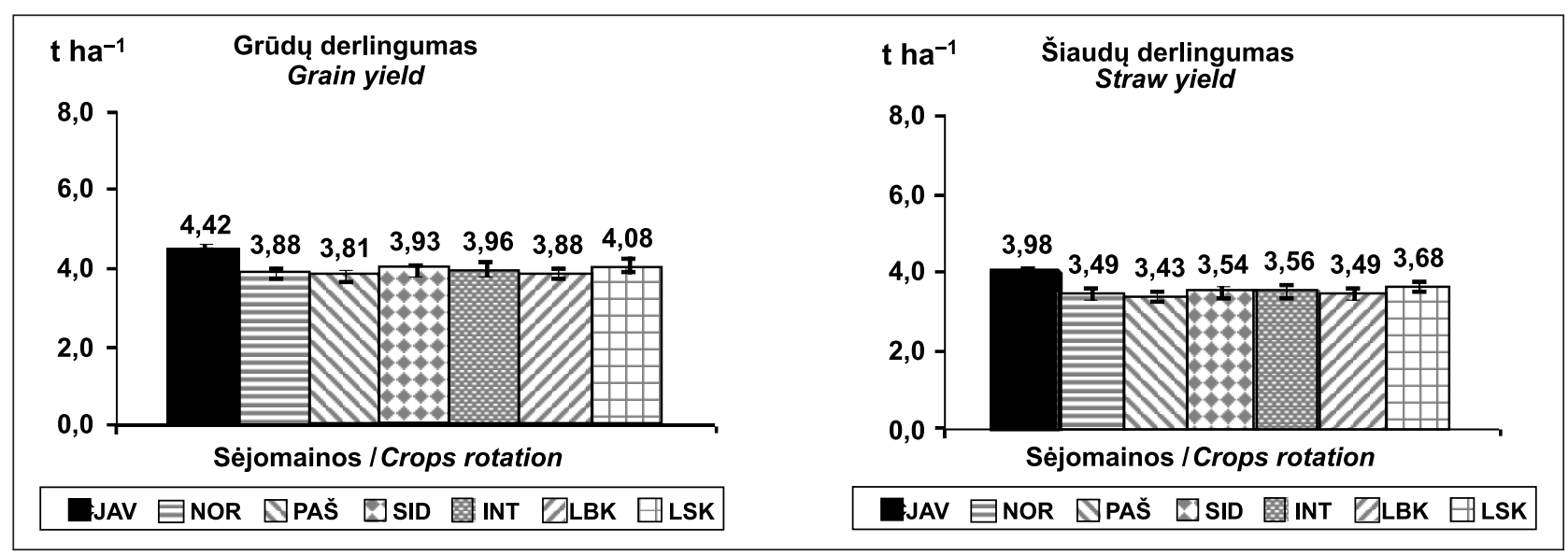

2 pav. Sëjomainų poveikis žieminių kviečiu derlingumui, 1967-2012 m. Sëjomainos: JAV - javų, NOR - Norfolko, LBK - lauko sejomaina be kaupiamųjų, LSK - lauko sëjomaina su kaupiamaisiais augalais

Fig. 2. Effect of crop rotation on winter wheat yield, 1967-2012. Crop rotation: JAV - cereal, NOR - Norfolk, LBK - field rotation without row crops, LSK - field rotation with row crops 
2 lentelè. Sẻjomainų ir priešsẻlių poveikis su žieminių kviečių derliumi išnešamų maisto medžiagų kiekiui, 1967-2012 m.

Table 2. Effect of crop rotation and preceding crop on nutrient content taken out with winter wheat yield, 1967-2012

\begin{tabular}{|c|c|c|c|c|}
\hline \multirow[b]{2}{*}{$\begin{array}{l}\text { Sëjomaina } \\
\text { Crop rotation }\end{array}$} & \multirow[b]{2}{*}{$\begin{array}{c}\text { Priešsèlis } \\
\text { Preceding crop }\end{array}$} & \multicolumn{3}{|c|}{$\begin{array}{l}\text { Maisto medžiagu kiekiai } \mathrm{kg} \mathrm{ha}^{-1} \\
\text { Nutrient content, } \mathrm{kg} \mathrm{ha}^{-1}\end{array}$} \\
\hline & & 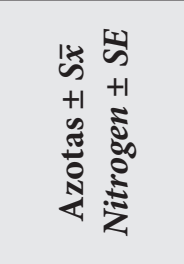 & 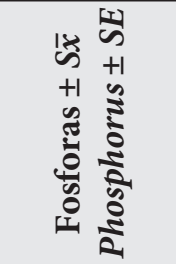 & 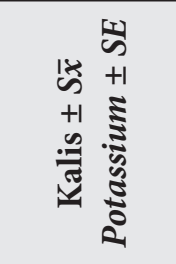 \\
\hline \multicolumn{5}{|c|}{ Su grūdais / with grain } \\
\hline Javų / Cereal & $\begin{array}{l}\text { Vikių ir avižų mišinys } \\
\text { Vetch-oat mixture }\end{array}$ & $48,5 \pm 6,80$ & $10,1 \pm 1,41$ & $11,4 \pm 1,59$ \\
\hline Norfolko / Norfolk & $\begin{array}{l}\text { Daugiametès žolès I n. m. } \\
\text { Perennial grasses of the first year of use }\end{array}$ & $80,0 \pm 3,54$ & $15,5 \pm 0,68$ & $18,1 \pm 0,80$ \\
\hline $\begin{array}{l}\text { Lauko be kaupiamujju / Field } \\
\text { rotation without row crops }\end{array}$ & Juodasis pūdymas / Black fallow & $74,4 \pm 3,36$ & $14,1 \pm 0,64$ & $15,8 \pm 0,71$ \\
\hline $\begin{array}{l}\text { Lauko su kaupiamaisiais } \\
\text { Field rotation with row crops }\end{array}$ & Juodasis pūdymas / Black fallow & $71,6 \pm 3,98$ & $13,6 \pm 0,76$ & $15,2 \pm 0,84$ \\
\hline \multicolumn{2}{|c|}{ Vidutiniškai / Average } & $65,9 \pm 3,58$ & $12,8 \pm 0,70$ & $14,5 \pm 0,80$ \\
\hline \multicolumn{5}{|c|}{ Su šiaudais / with straw } \\
\hline Javų / Cereal & $\begin{array}{l}\text { Vikių ir avižų mišinys } \\
\text { Vetch-oat mixture }\end{array}$ & $16,8 \pm 2,35$ & $2,3 \pm 0,32$ & $21,2 \pm 2,97$ \\
\hline Norfolko / Norfolk & $\begin{array}{l}\text { Daugiametès žolès I n. m. } \\
\text { Perennial grasses of the first year of use }\end{array}$ & $37,2 \pm 1,64$ & $6,2 \pm 0,27$ & $27,9 \pm 1,23$ \\
\hline $\begin{array}{l}\text { Lauko be kaupiamujjų / Field } \\
\text { rotation without row crops }\end{array}$ & Juodasis pūdymas / Black fallow & $29,7 \pm 1,34$ & $3,8 \pm 0,17$ & $28,0 \pm 1,26$ \\
\hline $\begin{array}{l}\text { Lauko su kaupiamaisiais } \\
\text { Field rotation with row crops }\end{array}$ & Juodasis pūdymas / Black fallow & $28,6 \pm 1,59$ & $3,7 \pm 0,21$ & $26,9 \pm 1,49$ \\
\hline \multicolumn{2}{|c|}{ Vidutiniškai / Average } & $26,8 \pm 1,42$ & $3,8 \pm 0,20$ & $25,0 \pm 1,40$ \\
\hline
\end{tabular}
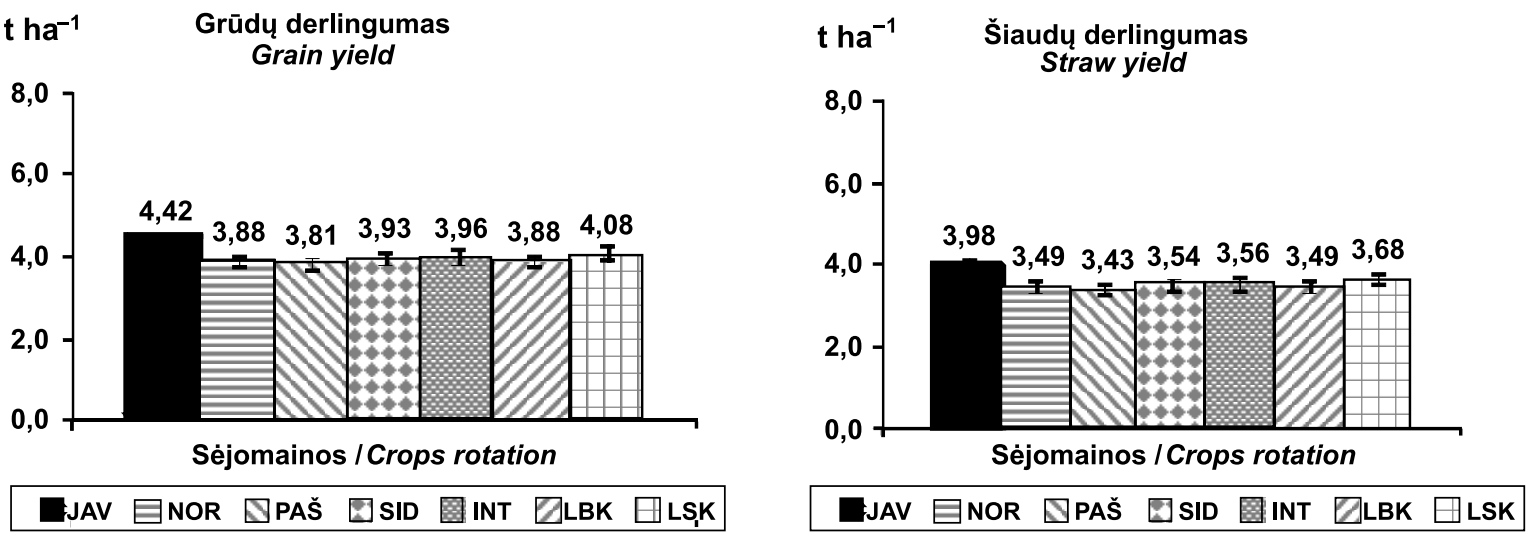

3 pav. Sëjomainų poveikis vasarinių miežių derlingumui, 1967-2012 m. Sëjomainos: JAV - javų, NOR - Norfolko, PAŠ - pašarinè, SID - sideraciné, INT - intensyvi, LBK - lauko sèjomaina be kaupiamujų, LSK - lauko sejjomaina su kaupiamaisiais augalais

Fig. 3. Effect of crop rotation on spring barley yield, 1967-2012. Crop rotation: JAV - cereal, NOR - Norfolk, $P A S$ - fodder, SIDL - green manure, INT - intensive, LBK - field rotation without row crops, LSK - field rotation with row crops 
$\left(r=-0,716^{*}\right)$, fosforo $\left(r=-0,322^{*}\right)$ bei kalio $\left(r=-0,302^{\star}\right)$ kiekių $\left(\mathrm{kg} \mathrm{t}^{-1}\right)$ grūduose. Didžiausi kiekiai azoto $\left(89,6 \mathrm{~kg} \mathrm{ha}^{-1}\right)$ ir fosforo $\left(17,9 \mathrm{~kg} \mathrm{ha}^{-1}\right)$ išnešami su vasarinių miežių grūdais, augintais lauko sejjomainoje be kaupiamųjų po žieminių rugių, o kalio $\left(20,8 \mathrm{~kg} \mathrm{ha}^{-1}\right)$ - javų sèjomainoje auginant juos po avižų priešsèlio ( 3 lentelè).

Azoto kiekis $\left(\mathrm{kg} \mathrm{t}^{-1}\right)$ vasarinių miežių šiauduose, didejant jų derlingumui $\left(\mathrm{t} \mathrm{ha} \mathrm{h}^{-1}\right)$, didejo $\left(r=0,594^{* *}\right)$. Tačiau priklausomumo tarp fosforo ir kalio kiekių šiauduose ir šiaudų derlingumo nenustatyta. Didžiausias kiekis azoto $\left(40,5 \mathrm{~kg} \mathrm{ha}^{-1}\right)$ susikaupe šiauduose, vasarinius miežius auginant pašarinèje sèjomainoje po pašarinių runkelių, fos- foro $\left(8,0 \mathrm{~kg} \mathrm{ha}^{-1}\right)$ bei kalio $\left(54,1 \mathrm{~kg} \mathrm{ha}^{-1}\right)$ - lauko sèjomainoje be kaupiamųjų po žieminių rugių priešsèlio.

Avižos. Remiantis vidutiniais 1967-2012 m. duomenimis, avižos geriausiai derèjo (grūdų derlingumas siekè 3,94, o šiaudų - 5,71 $\mathrm{t} \mathrm{ha}^{-1}$ ) auginant jas javų séjomainoje po žieminių kviečiu (4 pav.). Kiek mažesnis avižų derlingumas buvo jas auginant lauko sejomainoje su kaupiamaisiais augalais po vasarinių miežių ir mažiausias - trilaukejje sẻjomainoje po žieminių rugių.

Nustatyti neigiami tiesiniai labai stiprūs priklausomumai tarp avižų derlingumo $\left(\mathrm{t} \mathrm{ha}^{-1}\right)$ ir azoto kiekio $\left(\mathrm{kg} \mathrm{t}^{-1}\right)$ avižų grūduose $\left(r=-0,998^{\star *}\right)$ bei

3 lentelè. Séjomainų ir priešsẻlių poveikis su vasarinių miežių derliumi išnešamų maisto medžiagų kiekiui, 1967-2012 m.

Table 3. Effect of crop rotation and preceding crop on nutrient content taken out with spring barley yield, 19672012

\begin{tabular}{|c|c|c|c|c|}
\hline \multirow[b]{2}{*}{$\begin{array}{l}\text { Sèjomaina } \\
\text { Crop rotation }\end{array}$} & \multirow[b]{2}{*}{$\begin{array}{l}\text { Priešsèlis } \\
\text { Preceding crop }\end{array}$} & \multicolumn{3}{|c|}{$\begin{array}{l}\text { Maisto medžiagų kiekiai } \mathrm{kg} \mathrm{ha}^{-1} \\
\text { Nutrient content, } \mathrm{kg} \mathrm{ha^{-1 }}\end{array}$} \\
\hline & & 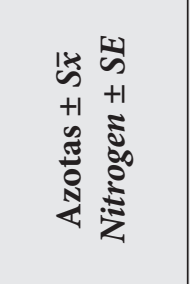 & 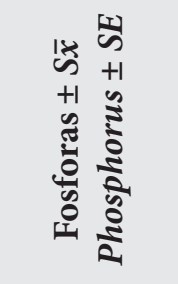 & 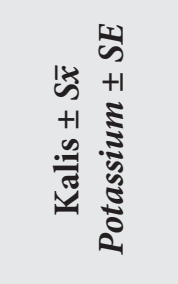 \\
\hline \multicolumn{5}{|c|}{ Su grūdais / with grain } \\
\hline Javų / Cereal & Avižos / Oat & $67,2 \pm 2,56$ & $15,9 \pm 0,61$ & $20,8 \pm 0,79$ \\
\hline Norfolko / Norfolk & Bulvès / Potatoes & $73,4 \pm 2,98$ & $15,1 \pm 0,62$ & $19,0 \pm 0,77$ \\
\hline Pašarinè / Fodder & Pašariniai runkeliai / Fodder beet & $70,9 \pm 2,88$ & $14,1 \pm 0,57$ & $17,9 \pm 0,73$ \\
\hline Sideracinè / Green manure & Bulvès / Potatoes & $74,3 \pm 3,20$ & $14,9 \pm 0,64$ & $18,9 \pm 0,81$ \\
\hline Intensyvi / Intensive & Kukurūzai / Corn & $74,9 \pm 3,08$ & $15,1 \pm 0,62$ & $19,0 \pm 0,78$ \\
\hline $\begin{array}{l}\text { Lauko be kaupiamųjų } \\
\text { Field rotation without row crops }\end{array}$ & Rugiai / Rye & $89,6 \pm 3,99$ & $17,9 \pm 0,79$ & $19,8 \pm 0,88$ \\
\hline $\begin{array}{l}\text { Lauko su kaupiamaisiais } \\
\text { Field rotation with row crops }\end{array}$ & Cukriniai runkeliai / Sugar beet & $76,8 \pm 2,90$ & $13,1 \pm 0,49$ & $18,0 \pm 0,68$ \\
\hline \multicolumn{2}{|c|}{ Vidutiniškai / Average } & $76,0 \pm 2,67$ & $15,2 \pm 0,54$ & $19,0 \pm 0,68$ \\
\hline \multicolumn{5}{|c|}{ Su šiaudais / with straw } \\
\hline Javų / Cereal & Avižos / Oat & $33,4 \pm 1,27$ & $6,0 \pm 0,23$ & $44,2 \pm 1,68$ \\
\hline Norfolko / Norfolk & Bulvès / Potatoes & $38,4 \pm 1,56$ & $5,2 \pm 0,21$ & $32,5 \pm 1,32$ \\
\hline Pašarinė / Fodder & Pašariniai runkeliai / Fodder beet & $40,5 \pm 1,65$ & $5,5 \pm 0,22$ & $27,1 \pm 1,10$ \\
\hline Sideracine / Green manure & Bulvès / Potatoes & $34,0 \pm 1,46$ & $5,7 \pm 0,24$ & $35,0 \pm 1,51$ \\
\hline Intensyvi / Intensive & Kukurūzai / Corn & $34,2 \pm 1,41$ & $5,7 \pm 0,24$ & $35,3 \pm 1,45$ \\
\hline $\begin{array}{l}\text { Lauko be kaupiamųų } \\
\text { Field rotation without row crops }\end{array}$ & Rugiai / Rye & $30,7 \pm 1,37$ & $8,0 \pm 0,36$ & $54,1 \pm 2,41$ \\
\hline $\begin{array}{l}\text { Lauko su kaupiamaisiais } \\
\text { Field rotation with row crops }\end{array}$ & Cukriniai runkeliai / Sugar beet & $30,1 \pm 1,14$ & $4,0 \pm 0,15$ & $21,7 \pm 0,82$ \\
\hline \multicolumn{2}{|c|}{ Vidutiniškai / Average } & $33,2 \pm 1,18$ & $5,7 \pm 0,21$ & $36,4 \pm 1,33$ \\
\hline
\end{tabular}




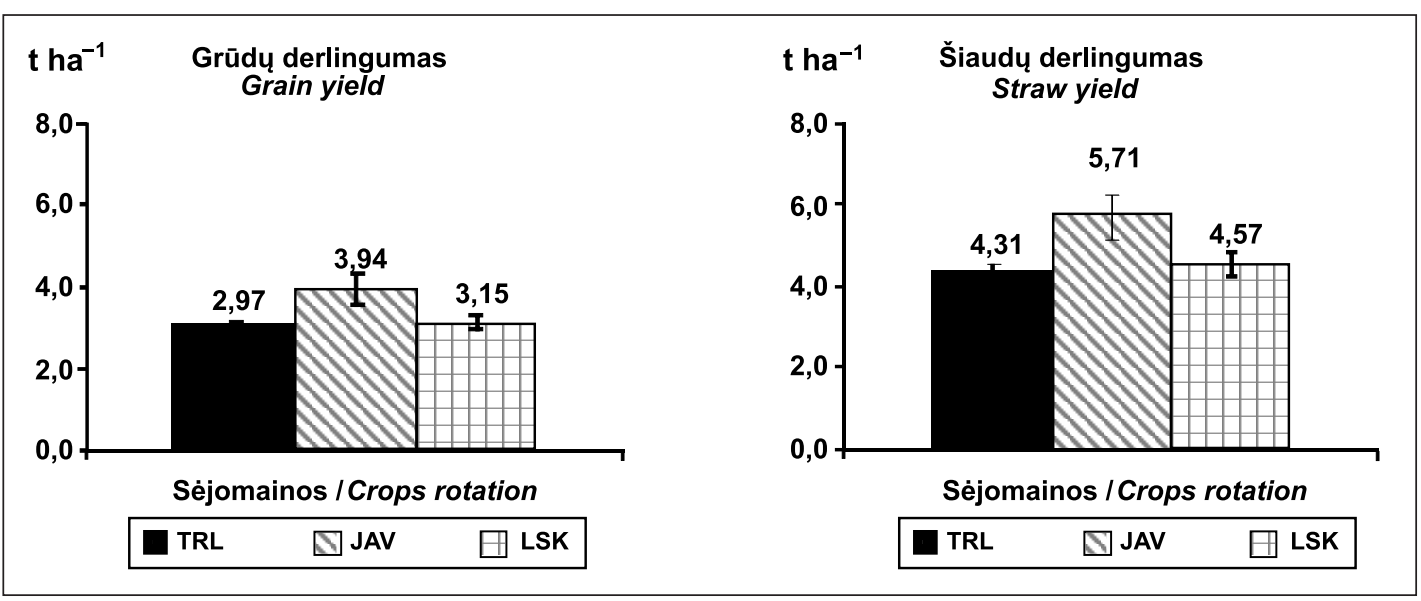

4 pav. Sejomainų poveikis avižų derlingumui, 1967-2012 m. Sejjomainos: TRL - trilaukè, JAV - javų, LSK - lauko sejjomaina su kaupiamaisiais augalais

Fig. 4. Effect of crop rotation on oat yield, 1967-2012. Crop rotation: TRI - three-course, $J A V$ - cereal, LSK - field rotation with row crops

šiauduose $\left(r=-0,991^{\star *}\right)$. Priklausomumai tarp avižų derlingumo $\left(\mathrm{t} \mathrm{ha}^{-1}\right)$ ir fosforo bei kalio kiekiu grūduose ir šiauduose nustatyti taip pat neigiami, bet silpnesni (fosforo: grūduose $-r=-0,873^{\star \star}$, šiauduose $-r=-0,341^{\star}$; kalio: grūduose $-r=-0,517^{\star}$, šiauduose $-r=-0,390^{\star}$ ).

Nors ir buvo nustatyti neigiami priklausomumai tarp avižų derlingumo ( $\left.\mathrm{t} \mathrm{ha}^{-1}\right)$ ir maisto me- džiagų kiekio $\left(\mathrm{kg} \mathrm{t}^{-1}\right)$ grūduose bei šiauduose, tačiau susikaupusių medžiagų kiekiai $\left(\mathrm{kg} \mathrm{ha}^{-1}\right)$ išliko didžiausi javų sèjomainoje auginant avižas po žieminių kviečių priešsèlio (4 lentelè).

Ši skirtumą lèmè po žieminių kviečių priešsèlio gautas ženkliai didesnis avižų derlingumas. Grūduose susikaupe azoto 24,3-31,7, fosforo - 21,531,3, kalio - 30,7-31,7 \% daugiau, o šiauduose

4 lentelè. Sẻjomainų ir priešsẻlių poveikis su avižų derliumi išnešamų maisto medžiagų kiekiui, 1967-2012 m. Tab le 4. Effect of crop rotation and preceding crop on nutrient content taken out with oat yield, 1967-2012

\begin{tabular}{|c|c|c|c|c|}
\hline \multirow[b]{2}{*}{$\begin{array}{l}\text { Sẻjomaina } \\
\text { Crop rotation }\end{array}$} & \multirow[b]{2}{*}{$\begin{array}{c}\text { Priešsèlis } \\
\text { Preceding crop }\end{array}$} & \multicolumn{3}{|c|}{ 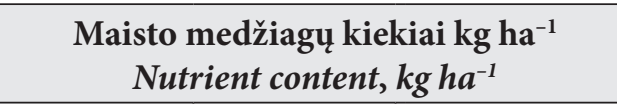 } \\
\hline & & 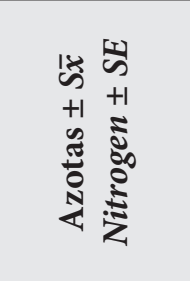 & 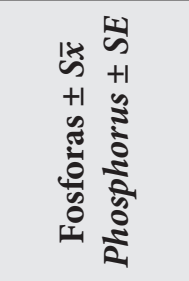 & 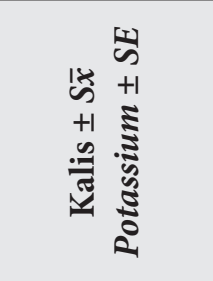 \\
\hline \multicolumn{5}{|c|}{ Su grūdais / with grain } \\
\hline Trilauke / Three-course & Žieminiai rugiai / Winter rye & $47,0 \pm 2,74$ & $9,9 \pm 0,56$ & $12,7 \pm 0,79$ \\
\hline Javų / Cereal & Žieminiai kviečiai / Winter wheat & $61,9 \pm 6,03$ & $13,0 \pm 1,27$ & $16,6 \pm 1,61$ \\
\hline $\begin{array}{l}\text { Lauko su kaupiamaisiais } \\
\text { Field rotation with row crops }\end{array}$ & Vasariniai miežiai / Spring barley & $49,8 \pm 3,07$ & $10,7 \pm 0,66$ & $12,6 \pm 0,78$ \\
\hline \multicolumn{2}{|c|}{ Vidutiniškai / Average } & $52,3 \pm 2,87$ & $11,0 \pm 0,60$ & $14,1 \pm 0,77$ \\
\hline \multicolumn{5}{|c|}{ Su šiaudais / with straw } \\
\hline Trilauke / Three course & Žieminiai rugia / Winter rye & $34,5 \pm 2,18$ & $6,0 \pm 0,32$ & $79,8 \pm 3,87$ \\
\hline Javų / Cereal & Žieminiai kviečiai / Winter wheat & $42,3 \pm 4,12$ & $8,0 \pm 0,78$ & $106,9 \pm 10,42$ \\
\hline $\begin{array}{l}\text { Lauko su kaupiamaisiais } \\
\text { Field rotation with row crops }\end{array}$ & Vasariniai miežiai / Spring barley & $35,7 \pm 2,20$ & $6,9 \pm 0,42$ & $97,9 \pm 6,02$ \\
\hline \multicolumn{2}{|c|}{ Vidutiniškai / Average } & $38,6 \pm 2,08$ & $6,7 \pm 0,37$ & $88,6 \pm 4,94$ \\
\hline
\end{tabular}


atitinkamai - 18,5-22,6, 15,9-33,3 ir 9,2-34,0\% daugiau nei kitose sèjomainose, auginant avižas po žieminių rugių ar po vasarinių miežių.

\section{IŠVADOS}

1. Javų derlingumas priklausė nuo taikytų sèjomainų ir priešsèlių. Žieminius rugius auginant sejomainose, jų derlingumas gautas $26,6-44,9 \%$ didesnis nei monopasèlyje. Žieminiai kviečiai, priešingai nei avižos, jautrūs didelei miglinių javų koncentracijai sejjomainoje. Avižos $\left(3,94 \mathrm{t} \mathrm{ha}^{-1}\right)$ ir miežiai $\left(4,42 \mathrm{t} \mathrm{ha}^{-1}\right)$ geriausiai derejo javų sejjomainoje auginant juos atitinkamai po žieminių kviečių ir avižų.

2. Didejjant žieminių rugių ir žieminių kviečių grūdų derlingumui ( $\left.\mathrm{t} \mathrm{ha}^{-1}\right)$ azoto $\left(r=0,429^{*}\right.$, $\left.r=0,836^{*}\right)$, fosforo $\left(r=0,516^{*}, r=0,918^{*}\right)$ ir kalio $\left(r=0,681^{\star \star}, r=0,735^{\star}\right)$ kiekiai $\left(\mathrm{kg} \mathrm{t}^{-1}\right)$ didejo, tačiau didejjant šiaudų derlingumui - didejo azoto $\left(r=0,413^{\star}, r=0,930^{\star *}\right)$, fosforo $\left(r=0,425^{\star}\right.$, $\left.r=0,773^{\star}\right)$ kaupimas, o kalio mažèjo $\left(r=-0,327^{\star}\right.$, $\left.r=-0,379^{\star}\right)$.

3. Azoto $\left(r=-0,716^{\star}, r=-0,998^{\star *}\right)$, fosforo $\left(r=-0,322^{\star}, r=-0,873^{*}\right)$ ir kalio $\left(r=-0,302^{*}\right.$, $\left.r=-0,517^{\star}\right)$ kiekiai vasarinių miežių ir avižų grūduose buvo atvirkščiai proporcingi ju derlingumui. Didejjant vasarinių miežių ir avižų šiaudų derlingumui, azoto kiekis mažèjo $\left(r=-0,594^{*}\right.$, $\left.r=-0,991^{\star *}\right)$. Fosforo ir kalio kiekiai mažèjo tik didejjant avižų šiaudų derlingumui. Patikimų priklausomumų tarp vasarinių miežių šiaudų derlingumo ir fosforo bei kalio kiekių juose nenustatyta.

Gauta 20141030 Priimta 20150330

\section{LITERATŪRA}

1. Aleinikovienè J. 2009. Pietu Lietuvos ariamu smèlžemiu renatūralizacija: cheminiai ir mikrofloros pokyčiai: daktaro disertacija. Kaunas. 94 p.

2. Bakšienė E., Ražukas A., Asakaviciute R. Kacergius A., Maknickiené Z., Romanovskaja R., Titova J., Tripolskaja L. 2013. Effects of ecological farming systems and five-year crop rotations on crop productivity and properties of haplic luvisol. Journal of Food, Agriculture \& Environment. Vol. 11(3-4). P. 1137-1142.

3. Breuning-Madsen H., Elberling B., Balstroem T., Holst M., Freudenberg M. A. 2009. Comparison of soil organic carbon stock in ancient and modern land use systems in Denmark. European Journal of Soil Science. Vol. 60. P. 55-63.

4. Feizienė D., Feiza V., Kadžienė G. 2008. Glèjiško rudžemio (Endocalcari-Epihypogleyic Cambisol) armens agrocheminių savybių pokyčiai taikant ilgametes žemdirbystès sistemas. Žemès ūkio mokslai. T. 15. Nr. 2. P. 1-12.

5. Greimas G. 2003. Tręšimo sistemų ịtaka skirtingų sejomainu augalų produktyvumui ir NPK balansui. Žemdirbystè. Nr. 4. P. 49-62.

6. Greimas G., Janušiienè V. 1994. Tręšimo sistemų itaka javų séjomainos produktyvumui bei dirvožemio derlingumui. Tręšimo sistemos ir dirvožemio derlingumas. Vilnius, P. 270-276.

7. Janušauskaitè D., Mašauskas V. 2006. Periodiško tręšimo fosforu ir kaliu itaka sẻjomainos produktyvumui ir dirvožemio biologinèms savybèms. Žemès ükio mokslai. Nr. 4. P. 11-21.

8. Lagomarsino A., Grego S., Marhan S., Moscatelli M. C., Kandeler E. 2009. Soil management modifies micro-scale abundance and function of soil microorganisms in a Mediterranean ecosystem. European Journal of Soil Science. Vol. 60. P. 2-12.

9. Mažvila J., Rainys K., Vaišvila Z., Arbačiauskas J., Adomaitis T. 2006. Lauko sèjomainos produktyvumo ir dirvožemio agrocheminių savybių skirtingo fosforingumo ir kalingumo dirvožemiuose priklausomumas nuo tręšimo sistemų. Žemdirbystè. T. 93. Nr. 3. P. 3-17.

10. Plesevičienė A., Gužys S. 1997. Tręšimo sistemų palyginimas rūgščiame ir kalkintame dirvožemiuose. Žemès ükio mokslai. Nr. 2. P. 3-10.

11. Šlepetienè A., Šlepetys J., Kavoliute F., Liaudanskienė I., Kadžiulienè Ž. 2007. Anglies, azoto, fosforo ir sieros pokyčiai Vakaru Žemaitijos natūraliose bei įvairiose agrarinèse žemėnaudose. Žemdirbystè. T. 94. Nr. 3. P. 90-99.

12. Tarakanovas P., Raudonius S. 2003. Agronominiu tyrimu duomenu statistine analizé taikant kompiuterines programas ANOVA, STAT, SPLIT-PLOT iš paketo SELEKCIJA ir IRRISTAT. Akademija, $57 \mathrm{p}$.

13. Tripolskaja L. 1994. Organiniu ir mineralinių trąšu naudojimo pašaru sèjomainoje velèniniame jauriniame priesmèlio dirvožemyje mokslinis pagrindimas: habilitacinis darbas. $128 \mathrm{p}$.

14. Tripolskaja L., Romanovskaja D., Slepetiene A., Razukas A., Sidlauskas G. 2014. Effect of the chemical composition of green manure crops on humus formation in a Soddy-Podzolic soil. Eurasian Soil Science. Vol. 47(4). P. 310-318.

15. Zakarauskaitė D., Grigaliūnienè K. 2001. Mineralinių ir organinių trąšų itaka hidrolizinių fermentų aktyvumui karbonatingame sekliai paglèjejusiame išplautžemyje. Vagos. Nr. 49(2). P. 50-54. 
Darija Jodaugienė, Vaclovas Bogužas,

Romutė Mikučionienė, Ingė Auželienė,

Romualdas Zemeckis

\section{EFFECT OF CROP ROTATION AND PRECEDING CROP ON NUTRIENT CONTENT TAKEN OUT WITH CEREAL YIELD}

Summary

A long-term field experiment was carried out at the Experimental Station of Aleksandras Stulginskis University during 1967-2012. The soil of the Experimental site is moderately fine textured Calc(ar)i-Endohypogleyic Luvisol. The aim of the experiment was to establish effect of crop rotation and preceding crop on nitrogen, phosphorus, potassium accumulation and its removal with the primary and secondary cereal yield production. During the 46-year research period, various agricultural crops were cultivated in different crop rotation: three-course, cereal, Norfolk, monoculture, green manure, intensive, six-course field rotation without row crops and eight-course crop rotations with row crops. Winter wheat (Triticum aestivum), winter rye (Secale cereale), spring barley (Hordeum vulgare L.) and oat (Avena sativa) were cultivated after various preceding crops in applied crop rotations. It was established that nutrient accumulation and its removal depends on the grain productivity and preceding crop. Correlation-regression analysis showed that nutrient content accumulated in the yield of primary and secondary production was different in winter and in spring cereal crops. With higher winter rye and winter wheat grain yield $\left(\mathrm{t} \mathrm{ha}{ }^{-1}\right)$, significantly higher content of nitrogen $\left(r=0.429^{*}\right.$, $\left.r=0.836^{\star}\right)$, phosphorus $\left(r=0.516^{*}, r=0.918^{*}\right)$ and potassium $\left(r=0.681^{\star *}, r=0.735^{\star}\right)\left(\mathrm{kg} \mathrm{t}^{-1}\right)$ was accumulated in cereal grains. With higher straw yield, nitrogen $\left(r=0.413^{*}\right.$, $\left.r=0.930^{* *}\right)$ and phosphorus $\left(r=0.425^{*}, r=0.773^{*}\right)$ accumulation significantly increased, but potassium $\left(r=-0.327^{*}\right.$, $\left.r=-0.379^{*}\right)$ accumulation decreased. The content of nitrogen $\left(r=-0.716^{\star}, r=-0.998^{\star *}\right)$, phosphorus $\left(r=-0.322^{\star}\right.$, $\left.r=-0.873^{\star}\right)$ and potassium $\left(r=-0.302^{\star}, r=-0.517^{\star}\right)$ in spring barley and oats was negatively proportional to their productivity. However, increase of the straw of spring barley and oat yield declined the content of nitrogen $\left(r=-0.594^{*}\right.$, $\left.r=-0.991^{* *}\right)$. No significant effect was found between the phosphorus and potassium quantity and the spring barley straw yield.

Key words: crop rotation, preceding crops, cereals, productivity, taken out nutrient content 